BOTANICA

ISSN 2538-8657

2020, 26(2): 109-115

\title{
COPRINELLUS DEMINUTUS (PSATHYRELLACEAE, AGARICOMYCETES), A RARE FUNGUS NEWLY RECORDED FROM RUSSIA
}

\author{
Olga S. Shiryaeva ${ }^{1 *}$, Olga G. KalmyKova ${ }^{2}$
}

${ }^{1}$ Institute of Plant and Animal Ecology, Ural Branch of the Russian Academy of Sciences, 8 March Str. 202, 620144 Ekaterinburg, Russia

${ }^{2}$ Steppe Institute, Ural Branch of the Russian Academy of Sciences, Pionerskaja Str. 11, 460000 Orenburg, Russia

*Corresponding author. E-mail: olga.s.shiryaeva@gmail.com

\begin{abstract}
Shiryaeva O.S., Kalmykova O.G., 2020: Coprinellus deminutus (Psathyrellaceae, Agaricomycetes), a rare fungus newly recorded from Russia. - Botanica, 26(2): 109-115.

Coprinellus deminutus is a very rare species that is known only from three localities in Europe. This paper presents new records of the species in Russia (two new localities in the protected areas of Orenburg Region, the European part of Russia). It expands this species geographic distribution to the Urals. A description of the species and its habitats is provided.
\end{abstract}

Keywords: dry grasslands, geographic distribution, Orenburg Region, Orenburg State Nature Reserve, protected area, steppe, xerothermic grasslands.

\section{INTRODUCTION}

The genus Coprinellus P.Karst. (Psathyrellaceae, Agaricomycetes) comprises coprinoid taxa that have deliquescent or collapsing basidiomata, hymeniform pileipellis, veil consisting of globose elements or chains of fusiform to ellipsoid or globose, thinwalled or partly thick-walled elements, or the veil is lacking (REDHEAD et al., 2001; NAGY et al., 2013). These fungi are common saprotrophs fruiting on soil, wood, herbs, litter and herbivore dung (KNUDSEN \& Vesterholt, 2018). The genus Coprinellus encompasses approximately 80 described species (NAGY et al., 2012). Only 27 species of Coprinellus have been reported from Russia, i.e. C. amphithallus (M.Lange et A.H. Sm.) Redhead, Vilgalys et Moncalvo, C. angulatus (Peck) Redhead, Vilgalys et Moncalvo, $C$. bisporus (J.E. Lange) Vilgalys, Hopple et Jacq. Johnson, C. callinus (M.Lange \& A.H. Sm.) Vilgalys, Hopple et Jacq. Johnson, C. congregatus (Bull.) P.Karst., C. curtus (Kalchbr.) Vilgalys, Hopple et
Jacq. Johnson, C. dilectus (Fr.) Redhead, Vilgalys et Moncalvo, $C$. disseminatus (Pers.) J.E. Lange, C. domesticus (Bolton) Vilgalys, Hopple et Jacq. Johnson, C. ellisii (P.D. Orton) Redhead, Vilgalys et Moncalvo, C. ephemerus (Bull.) Redhead, Vilgalys et Moncalvo, C. flocculosus (DC.) Vilgalys, Hopple et Jacq. Johnson, C. heptemerus (M.Lange et A.H. Sm.) Vilgalys, Hopple et Jacq. Johnson, C. impatiens (Fr.) J.E. Lange, C. marculentus (Britzelm.) Redhead, Vilgalys et Moncalvo, C. micaceus (Bull.) Vilgalys, Hopple et Jacq. Johnson, C. pallidissimus (Romagn.) P.Roux, Guy García et S.Roux, C. pellucidus (P.Karst.) Redhead, Vilgalys et Moncalvo, C. plagioporus (Romagn.) Redhead, Vilgalys et Moncalvo, C. radians (Desm.) Vilgalys, Hopple et Jacq. Johnson, C. sassii (M.Lange et A.H. Sm.) Redhead, Vilgalys et Moncalvo, C. silvaticus (Peck) Gminder, C. subdisseminatus (M.Lange) Redhead, Vilgalys et Moncalvo, C. subimpatiens (M.Lange et A.H. Sm.) Redhead, Vilgalys et Moncalvo, C. subpurpureus (A.H. Sm.) Redhead, Vilgalys et Moncal- 
vo, C. truncorum (Scop.) Redhead, Vilgalys et Moncalvo, C. xanthothrix (Romagn.) Vilgalys, Hopple et Jacq. Johnson (Beglyanova, 1972; MikhaylovskiY, 1975; Bulakh, 1977, 2008; Ivanov, 1983; Ivanov \& Nezdojminogo, 1990; Ivanov \& Ivanova, 1997; Lazareva, 1998; Karatygin et al., 1999; Perova \& Gorbunova, 2001; Sopina, 2001; Svetasheva, 2004; Kirillova, 2006; Marina, 2006; Popov et al., 2007; Desyatova, 2008; Malysheva \& Malysheva, 2008; Perevedentseva, 2008; Sarycheva et al., 2009; Kovalenko, 2012; Palamarchuk, 2012; Rebriev et al., 2012; KoropachinskiY \& Banaev, 2014; BolshaKov et al., 2018).

During the explorations of the agaricoid fungi in the protected areas of Orenburg Region, a species new to Russia from this genus, namely Coprinellus deminutus, was recorded. Coprinellus deminutus is a very rare species that is known in Europe only. It has been reported from Germany (locus typicus, ENDERLE, 2004), Hungary (NAGY, 2005) and Ukraine (PrydiuK, 2014).

This research aimed to present new records of C. deminutus in Russia, including two new localities in Orenburg Region, the European part of Russia, and to characterise the species and its habitats.

\section{MATERIALS AND METHODS}

\section{Data sampling}

The specimens were collected by O.S. Shiryaeva in 2016 and 2018 in two localities in Orenburg Region: "Burtinskaya Steppe" and "Urochische Guylisma" (Fig. 1). O.G. Kalmykova made the descriptions

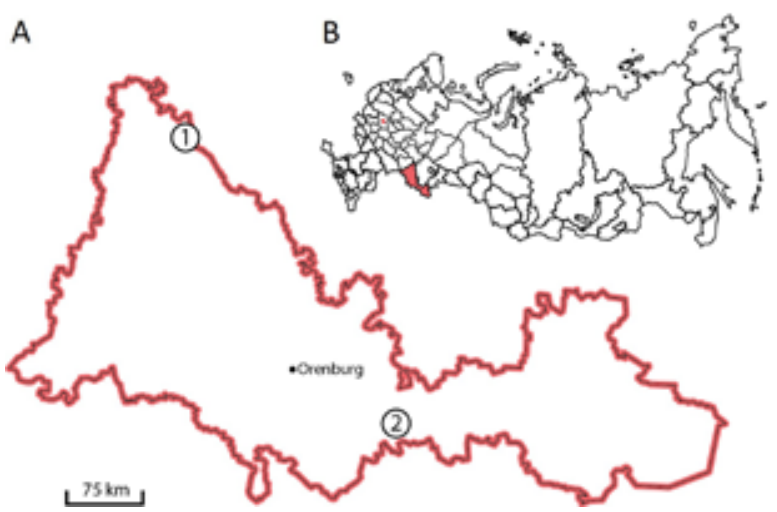

Fig. 1. Geographic location of the studied areas: A - Urochische Guylisma (1) and Burtinskaya Steppe (2) in Orenburg Region, B - Orenburg Region in Russia of plant communities of the studied sites in the same years. Plant communities were named after their dominant species.

Brief description of the species was based on the authors' observations and measurements. Microscopic features were described from the material mounted in $5 \% \mathrm{KOH}$, and $1 \%$ Congo red in concentrated $\mathrm{NH}_{4} \mathrm{OH}$. The specimens were examined using Leica DM 2000 light microscope. Measurements were based on observing 20 basidiospores, ten cystidia and basidia per collection. The quotient of length and width of the spores was reported as Q, and the arithmetic mean of the quotients was reported as Qav. The fungus was named after NAGY et al. (2012). The specimens are deposited at the Museum of the Institute of Plant and Animal Ecology (SVER).

\section{Study areas}

"Burtinskaya Steppe" is a cluster of the Orenburg State Nature Reserve that is one of the largest steppe reserves in Russia. This cluster is in the central part of Orenburg Region. It covers an area of 4.500 hectares within western foothills of the Southern Urals. Elevations in the area range from about $230 \mathrm{~m}$ to $420.9 \mathrm{~m}$ above sea level (a.s.l.). The mean annual temperature is $+4.3^{\circ} \mathrm{C}$. The climate is continental with a cold winter (January $-15.8^{\circ} \mathrm{C}$ ) and a dry, warm summer $\left(\right.$ July $\left.+22^{\circ} \mathrm{C}\right)$. The annual average precipitation is 300-350 mm (CHIBILEV, 2014). The average height of the snow cover is $19.4 \mathrm{~cm}$ (Anonymous, 2004). The hydrographic network is formed by the small rivers Tuzlukkol and Karagashty and the drying streams of Beloglinka, Kyzylsai, Tavolgasay, Dusansai (CHIBILEV, 2014). The area of "Burtinskaya Steppe" lies in the northern subzone of the steppe vegetation zone (Safronova \& Kalmykova, 2012). The steppes prevail in the area (Fig. 2). The plant communities from the formations of Stipeta zalesskii, Stipeta lessingianae, Helictotricheta desertorum, Poeta transbaicalicae, Festuceta valesiacae, Galatelleta villosae are dominant. Meadows and fragments of forests are located along the banks of the streams, in places with the close location of groundwater, and at the foot of the hills. Soil cover in the area is represented by chernozem (KaLMYKova \& SoroKa, 2017).

"Urochische Guylisma" is a protected area located in the western part of Orenburg Region within the East-European Plain. It covers an area of 12 hectares. 


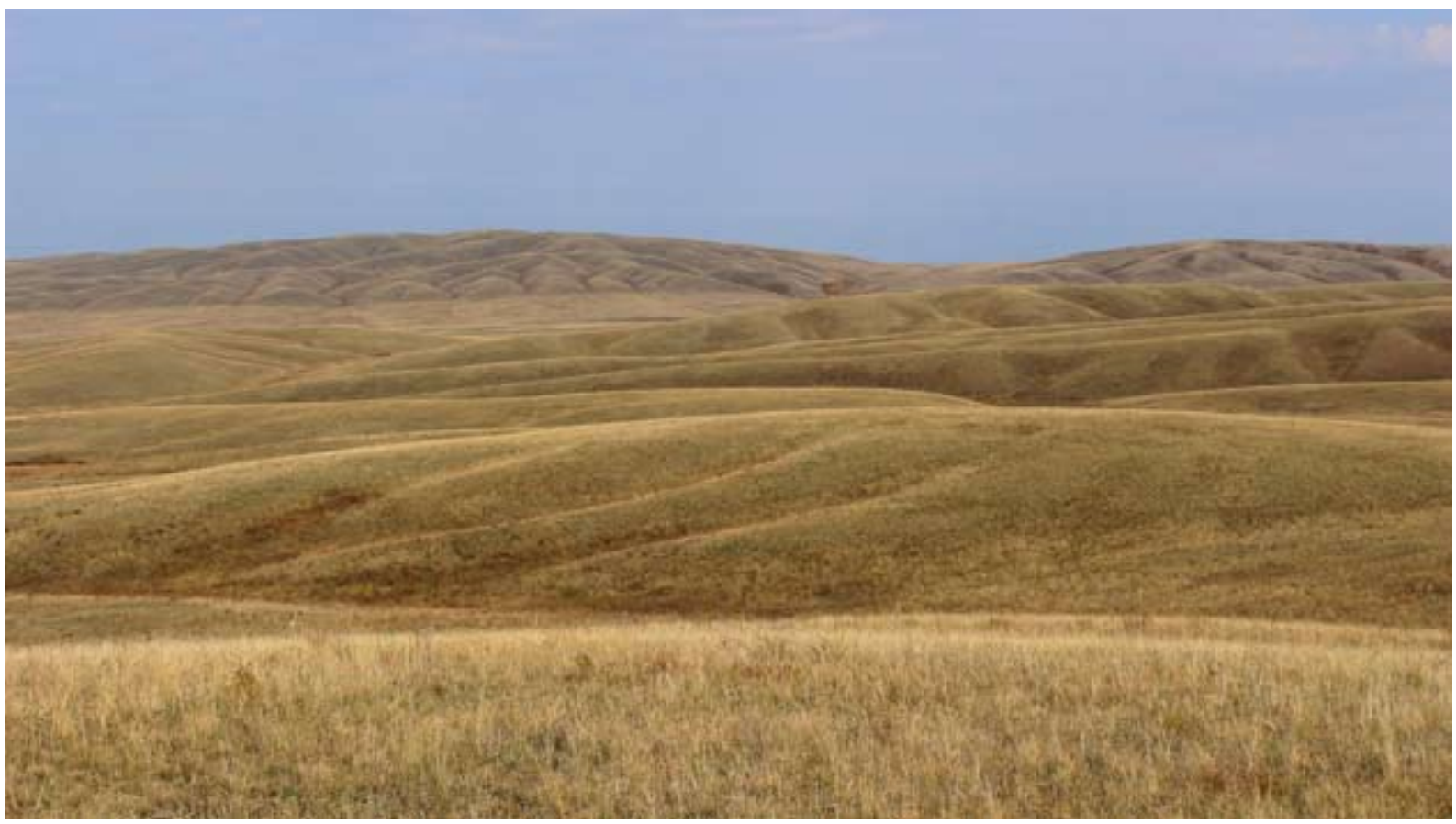

Fig. 2. The landscape of the protected area "Burtinskaya Steppe". Photo by O. S. Shiryaeva

It is a high plateau-like plain, which is divided by the ravine. Elevation at the highest place is $274.3 \mathrm{~m}$ a.s.1. The mean annual temperature is $+3.1^{\circ} \mathrm{C}$. The coldest month is January with mean temperature $-14.8^{\circ} \mathrm{C}$, the warmest is July with mean temperature $+20.3^{\circ} \mathrm{C}$. The annual mean precipitation is $350-400 \mathrm{~mm}$ (CHIBILEV et al., 2006). The average height of the snow cover (Abdulino) is $20.4 \mathrm{~cm}$ (AnONymous, 2004). There is a sparse Baban-Kasha spring at the bottom of the ravine. The area is situated in the southern subzone of the forest-steppe vegetation zone. The lower and middle parts of the steppe slope are occupied by plant communities of the Stipeta capillatae formation with abundant forbs. Shrubs (Caragana frutex (L.) K.Koch, Amygdalus nana L.) are also found. In the upper part of the slope, phytocenoses of the Stipeta pulcherrimae formation are common. At the outcrops, there are petrophyte-steppe plant communities. The formation of Helictotricheta desertorum dominates in the plateau-like top. Chernozem forms the soil cover in the area.

\section{RESULTS}

Coprinellus deminutus (Enderle) L.Nagy, Házi, Vágvölgyi et Papp, a rare European species previous- ly unknown in Russia, was recorded in two protected areas of Orenburg Region ("Burtinskaya Steppe" and "Urochische Guylisma") during the species inventory. Three specimens of $C$. deminutus were found fruiting on the soil in steppes. Below we provide the species description with illustrations based on the studied collections from Russia (Fig. 3) and the characteristics of habitats. The data on specimens examined are also presented and include location (country, region, district, protected area, and geographic coordinates), habitat (name of plant formation), substrate, collection date, acronym and the number of collection.

\section{Species description}

Macroscopic features. The specimens had small basidiomata. The pileus was $5-10 \mathrm{~mm}$ in diam., ellipsoid, becoming expanding, quickly deliquescent, and translucently striate to sulcate from the margin up to centre. It was whitish to pale grey with the pale brownish, ochraceous or fulvous centre. Pileus had a surface with whitish, cream, pale brownish, ochraceous or fulvous velar patches. Lamellae free, distant, whitish, when young, becoming greyish on ageing. Stipe $53-75 \mathrm{~mm}$ long, $0.5-1 \mathrm{~mm}$ thick, cylindrical, filiform, glabrescent, white. The smell indistinct. 

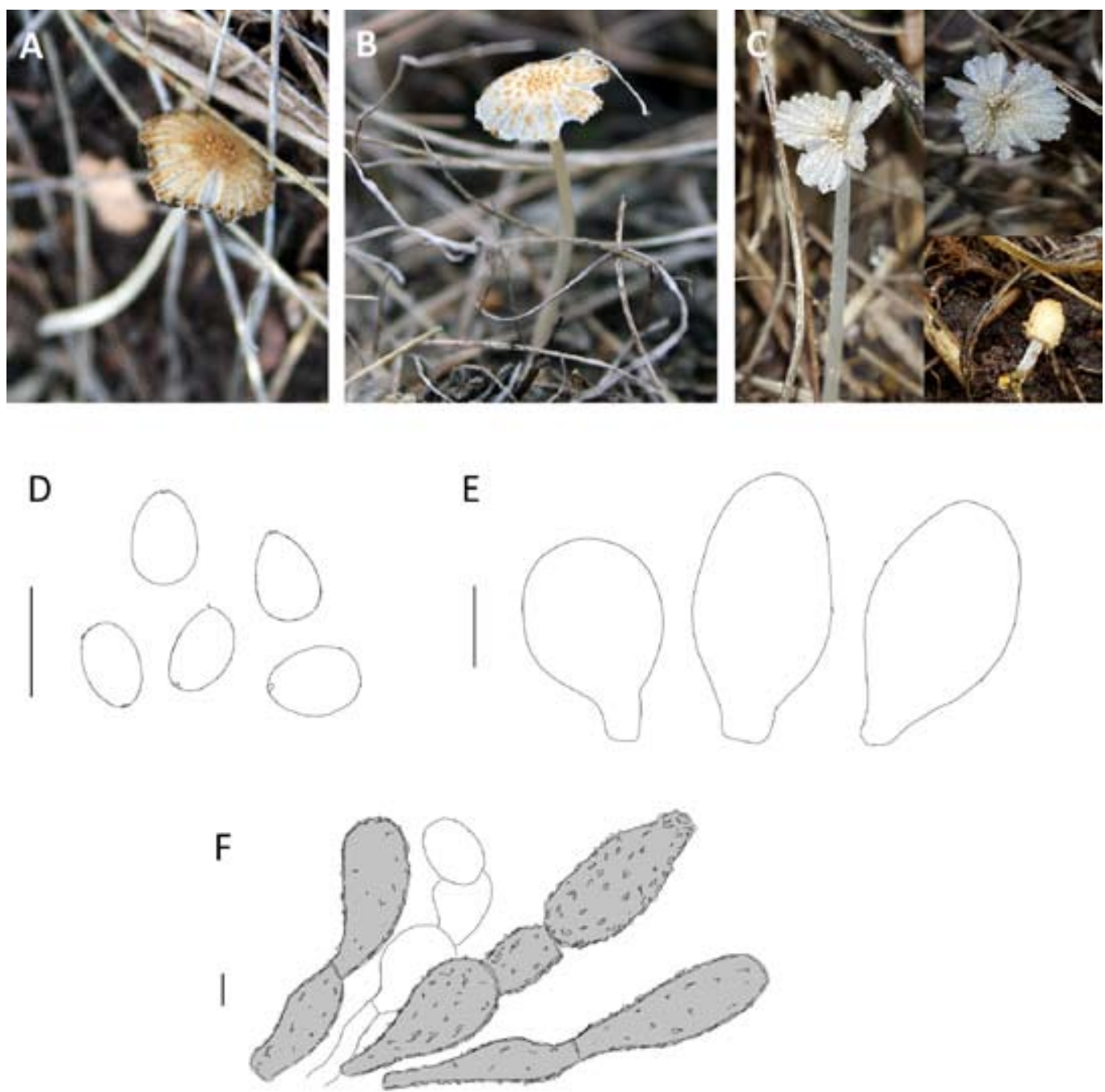

Fig. 3. Coprinellus deminutus - macro- and microfeatures. A - fruiting body (SVER 910701), B - fruiting body (SVER 910702), C - fruiting bodies (SVER 910703), D - basidiospores, E - cheilocystidia, F - veil elements. Scale bars $=10 \mu \mathrm{m}$

Microscopic features. Basidiospores were 7-10 $(10.5) \times 5-6(6.5) \mu \mathrm{m}$ with $\mathrm{Q}=1.30-1.68$ and $\mathrm{Q}^{*}$ $=1.46$, ellipsoid, not phaseoliform, red-brown, not opaque, with central germ-pore. Basidia were 20-29 $\times 8-10 \mu \mathrm{m}$, clavate, with four sterigmata. Cheilocystidia were $25-40 \times 13-25 \mu \mathrm{m}$, clavate, ellipsoid. Pleurocystidia were not found. Pileipellis was an epithelioid hymeniderm. Pileo- and caulocystidia were absent. The veil was composed of chains of subglobose, fusoid, cylindrical elements, colourless, pale to bright brown pigmented, partly thick-walled and encrusted. Clamp connections were not found.

Specimens examined. Russia, Orenburg Region, Belyaevka District, Orenburg State Nature Reserve, “Burtinskaya Steppe", 51 ${ }^{\circ} 12.636^{\prime} \mathrm{N}, 56^{\circ} 44.337^{\prime} \mathrm{E}$,
Stipeta zalesskii, on soil, 4 October 2016 (SVER 910701); ibid., $51^{\circ} 12.252^{\prime} \mathrm{N}, 56^{\circ} 40.644^{\prime} \mathrm{E}$, Stipeta lessingianae, on soil, 6 October 2016 (SVER 910702); Abdulino District, "Urochische Guylisma"

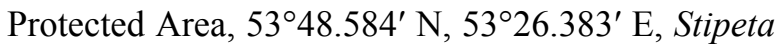
capillatae, on soil, 30 August 2018 (SVER 910703).

Morphological features of the studied specimens fit well to the description of $C$. deminutus presented in previous studies (ENDERLE, 2004; NAGY, 2005; PrYDIUK, 2014). The distinguishing features of C. deminutus include small basidiomata, veil consisting of chains of subglobose, fusoid, cylindrical elements, partly thick-walled and encrusted, rather small basidiospores, the absence of pleuro-, pileo-, and caulocystidia and its occurrence on the soil. This 
is the smallest species of the subsection Domestici Singer. The species similar in size and shape of basidiomata and phylogenetic position in the Domestici clade (NAGY et al., 2012) is C. curtus. It differs from C. deminutus by having larger basidiospores, pileoand caulocystidia, the veil of sphaerocysts and by its occurrence on dung (UlJÉ, 2001; NAGY, 2005).

\section{Habitats}

Coprinellus deminutus was found in protected areas of "Burtinskaya Steppe" and "Urochische Guylisma", the distance between them was about $360 \mathrm{~km}$. Coprinellus deminutus was recorded twice in the "Burtinskaya Steppe". The distance between these sites was about $4 \mathrm{~km}$.

The first site in the locality "Burtinskaya Steppe" was in the upper levelled part of the hill slope. The site burned out in 1998, 2003, 2005, 2009 and 2014. In 2016, the vegetation was represented by Stipetum zalesskii stiposo lessingianae-herbosum stepposae with Helictotrichon desertorum (Less.) Nevski and petrophyte species plant community. Plant cover was $78-80 \%$. The xerophytic firm-bunch grass Stipa zalesskii Wilensky was dominant, while Stipa lessingiana Trin. et Rupr. was co-dominant in the plant community. The grasses with a considerable abundance were: Festuca valesiaca Gaudin, Koeleria cristata (L.) Pers., Helictotrichon desertorum, Poa transbaicalica Roshev. The dominant species of forbs include Nepeta ucrainica L., Galium octonarium (Klokov) Soó, Palimbia salsa (L.fil.) Bess. The steppe petrophytic semishrubs (Eremogone koriniana (Fisch. ex Fenzl) Ikonn., Oxytropis spicata (Pall.) O.Fedtsch. et B.Fedtsch., Onosma simplicissima L.) played a significant role in the vegetation. We should note that by 2019 , due to recovery of vegetation after the fire, the phytocoenotic role of Stipa lessingiana significantly increased, while $S$. zalesskii moved to the rank of co-dominant.

The second site was on the plane. The site burned out in 1998, 2003 and 2009. In 2016, the vegetation was represented by Stipetum lessingianae festucoso valesiacae-herbosum stepposae with Artemisia marschalliana Spreng. plant community. Plant cover was $90 \%$. The phytocenosis edificator was Stipa lessingiana, co- edificator - Festuca valesiaca. The steppe mesoxerophytic forbs (Scorzonera austriaca Willd., Potentilla humifusa Willd. ex Schltdl.,
Taraxacum serotinum (Waldst. et Kit.) Poir., Medicago romanica Prodan) were abundant. Artemisia marschalliana, Astragalus macropus Bunge were significant among the semishrubs.

At the locality "Urochische Guylisma", C. deminutus was found in Stipetum capillatae herbosum meadow steppe plant community with Caragana frutex. Plant cover was $95 \%$. The plant community was dominated by the xerophytic firm-bunch grass Stipa capillata L. Forbs were abundant and diverse. Salvia nutans L. predominated. Salvia verticillata L., Achillea nobilis L., Astragalus onobrychis L., Pimpinella saxifraga L., Echinops ruthenicus M.Bieb., Gypsophila altissima L., Verbascum lychnitis L., Stachys recta L., Medicago romanica, Adonis vernalis L., Anemone sylvestris L., Galium ruthenicum Willd., Thalictrum minus L., Plantago urvillei Opiz, Eremogone longifolia (M.Bieb.) Fenzl, Fragaria viridis (Duchesne) Weston were represented in the plant community.

\section{DISCUSSION}

All known localities of $C$. deminutus, including the new ones, are in Europe (ENDERLE, 2004; NAGY, 2005; Prydiuk, 2014). The new localities are much further east, approximately $1.600 \mathrm{~km}$, from the nearest known site in Ukraine. The easternmost one of new localities is in the Urals, at the border between Europe and Asia. So, new records of $C$. deminutus extend its distributional range eastward to the Urals. It is expected to be more widespread, although not common.

All three studied collections of $C$. deminutus were found in steppes. These xerothermic grasslands are natural habitats formed by zonal climatic and soil factors, namely, high temperatures and large insolation, low precipitation level and limestone substrate. The studied sites are located in the protected areas, where haymaking and pastures are not allowed. Frequent fires affect ecosystems in two of these places. Interestingly, the species has also been mentioned for the xerothermic grasslands previously (NAGY, 2005; PRYDIUK, 2014). In Hungary, the species has been found in the plant community named Cynodonti-Festucetum pseudovinae, sub Carduus acanthoides L. (NAGY, 2005). The name of the plant community, in which the fungus has been discovered in Ukraine, is 
not indicated, but it is reported to be a dry meadow (Prydiuk, 2014). So, C. deminutus seems to be thermophilous, occurring in warm and dry places.

\section{ACKNOWLEDGEMENTS}

We are very grateful to Pavel Velmovsky (Orenburg, Russia) for preparing the map, and anonymous reviewers for many valuable remarks on the manuscript.

\section{REFERENCES}

Anonymous 2004: Reliable Prognosis. https://rp5.ru. [Accessed 7 December 2019].

Beglyanova M.I., 1972: Flora agarikovyx gribov južnoj časti Krasnojarskogo kraja. - Krasnojarsk. Bolshakov S.Yu., Volobuev S.V., Potapov K.O., Shiryaev A.G., Shiryaeva O.S., Ezhov O.N., Rebriev Yu.A., Palamarchuk M.A., Khimich Yu.R., Borovichev E.A., Zmitrovich I.V., 2018: New species for regional mycobiotas of Russia. 3. Report 2018. - Mikologija i Fitopatologija, 52(6): 386-397. https://doi.org/10.1134/ S0026364818060028

Bulakh E.M., 1977: Makromicety lesov verxnej časti bassejna r. Ussuri. - Mikologija i Fitopatologija, 11(3): 177-181.

BulakH E.M., 2008: Species of agaricoid fungi new for Russia and Russian Far East. - Mikologija i Fitopatologija, 42(5): 417-425.

Chibilev A.A., 2014: The "Orenburgsky Reservation": history of organization and nature diversity. - Ekaterinburg.

Chibilev A.A., Damrin A.G., Petrishchev V.P., Zhuravlev A.A., 2006: Abdulinskij rajon Orenburgskoj oblasti: Krajevedčeskij atlas. - Orenburg.

Desyatova O.A., 2008: Agarikoidnye bazidiomicety Orenburgskoj oblasti. Dissertacija kandidata biologičeskix nauk. - Moscow.

Enderle M., 2004: Der Kleine Erd-Tintling, Coprinus deminutus Enderle. - Zeitschrift für Mykologie, 70(2): 157-159.

Ivanov A.I., 1983: K flore agarikovyx gribov Penzenskoj oblasti. III - Novosti sistematiki niz ix rastenij, 20: 76-83.

Ivanov A.I., Ivanova V.A., 1997: Macromycetes of ruderal habitats on the Penza Region. I. The species composition. - Mikologija i Fitopatologija, 31(4): 10-13.

Ivanov A.I., Nezdojminogo E.L., 1990: K flore agarikovyx gribov Penzenskoj oblasti. VIII. - Novosti sistematiki niz ix rastenij, 27: 63-66.

Kalmykova O.G., Soroka O.V. (eds), 2017: The experience of monitoring steppe ecosystems affected by a grassland fire: approaches and methods. - Orenburg.

Karatygin I.V., Nezdoiminogo E.L., NovozhILov Yu.K., Zhurbenko M.P., 1999: Russian Arctic Fungi. Check-list. - Saint Petersburg.

Kirillova O.S., 2006: Agaricoid fungi of the National Park "Russky Sever" (Vologda Region). I. - Mikologija i Fitopatologija, 40(5): 377-386.

Knudsen H., Vesterholt J. (eds), 2018: Funga Nordica: Agaricoid, boletoid, clavarioid, cyphelloid and gastroid genera. - Copenhagen.

Koropachinskiy I.Yu., Banaev E.V. (eds), 2014: Plant diversity of Central Siberian Botanical Garden, SB RAS. - Novosibirsk.

Kovalenko A.E. (ed.), 2012: Micobiota of the Belorus-Valday Lakeland. - Moscow, Saint Petersburg.

Lazareva O.L., 1998: Cap fungi of Yaroslavl Region. - Mikologija i Fitopatologija, 32(6): 24-31.

Malysheva V.F., Malysheva E.F., 2008: The higher basidiomycetes in forest and grassland communities of Zhiguli. - Moscow, Saint Petersburg.

Marina L.V., 2006: Agaricoid basidiomycetes of the Visim Nature Reserve (Middle Urals). - Saint Petersburg.

MikhaylovskiY L.V., 1975: Novye dlja mikoflory SSSR vidy agarikovyx gribov iz Xibinskogo gornogo massiva. - Novosti sistematiki niz ix rastenij, 12: 205-212.

NAGY L., 2005: Additions to the Hungarian mycobiota 2. Coprinus and Tricholoma. - Österreichische Zeitschrift für Pilzkunde, 14: 291-301.

NAgy L.G., HÁzi J., VÁgVÖLgyi C., PAPP T., 2012: Phylogeny and species delimitation in the genus Coprinellus with special emphasis on the haired species. - Mycologia,104: 254-275. https://doi. org/10.3852/11-149

Nagy L.G., Vágvölgyi C., Papp T., 2013: Morphological characterization of clades of the Psathyrellaceae (Agaricales) inferred from a multigene 
phylogeny. - Mycological Progress, 12(3): 505517. https://doi.org/10.1007/s11557-012-0857-3

PalamarchuK M.A., 2012: Agaricoid basidiomycetes of the Pechoro-Ilych Reserve (North Urals). Syktyvkar.

Perevedentseva L.G., 2008: Konspekt agarikoidnyx basidiomicetov Permskogo Kraja. - Perm.

Perova N.V., Gorbunova I.A., 2001: Makromicety juga Zapadnoj Sibiri. - Novosibirsk.

Popov E.S., Morozova O.V., Kotkova V.M., Novozhilov Yu.K., Zhurbenko M.P., ZmitroVICH I.V., Kovalenko A.E.., 2007: Preliminary list of Fungi and Myxomycetes of Leningrad region compiled for scientific excursion in frame of the XV CEM. - Saint Petersburg.

PRYDIUK M.P., 2014: New and rare for Ukraine species of the family Coprinaceae. 4. Genus Coprinus (section Veliformes). - Ukrainian Botanical Journal, 71(4): 496-501. https://doi.org/10.15407/ ukrbotj71.04.496

Rebriev Yu.A., Rusanov V.A., Bulgakov T.S., Svetasheva T.Yu., Zmitrovich I.V., Popov E.S., 2012: Mycobiota of the arid territories of the south-west of Russia. - Rostov-on-Don.
Redhead S.A., Vilgalys R., Moncalvo J.M., Johnson J., Hopple J.S., 2001: Coprinus Persoon and the disposition of Coprinus species sensu lato. - Taxon, 50: 203-241. https://doi. org/10.2307/1224525

Safronova I.N., Kalmykova O.G., 2012: Problems of zonality and a role of the Nature Reserves in their solving. - Izvestia of Samara Scientific Center of the Russian Academy of Sciences, 1(6): 1638-1641.

Sarycheva L.A., Svetasheva T.Yu., Bulgakov T.S., Popov E.S., Malysheva V.F., 2009: Mycobiota of Lipetsk Region. - Voronezh.

Sopina A.A., 2001: Agarikojdnye bazidiomicety gornyx lesov bassejna r. Beloj (SeveroZapadnyj Kavkaz). Dissertacija kandidata biologičeskix nauk. - Saint Petersburg.

Svetasheva T.Yu., 2004: Agarikoidnye bazidiomicety Tulskoj oblasti. Dissertacija kandidata biologičeskix nauk. - Moscow.

UlJÉ K., 2001: Kees Uljé Coprinus site. https:/grzyby.pl/coprinus-site-Kees-Uljee/cindex.htm [Accessed 20 December 2019].

\section{COPRINELLUS DEMINUTUS (PSATHYRELLACEAE, AGARICOMYCETES), RETAS NAUJAI APRAŠYTAS GRYBAS RUSIJOJE}

\section{Olga S. Shiryaeva, Olga G. KalmyKova}

\section{Santrauka}

Coprinellus deminutus yra labai reta grybų rūšis, yra žinomos vos trys jos radavietės Europoje. Straipsnyje pateikiami duomenys apie dvi naujas rūšies radavietes saugomose Orenburgo regiono teritorijose, europineje Rusijos dalyje. Nauji duomenys rodo, kad C. deminutus paplitusi iki pat Uralo. Straipsnyje pateiktas detalus rūšies bei jos augaviečių aprašymas. 